УДК $811.161 .2+003.6$

DOI https://doi.org/10.26661/2414-1135-2021-84-38

\title{
ЛІНГВОСЕМІОТИЧНІ КОДИ ТА СПЕЦИФІКА ФУНКЦІОНУВАННЯ ЇХНІХ РІЗНОВИДІВ У ПУБЛІЦИСТИЧНИХ КІНОТЕКСТАХ
}

\author{
Щербак О. В. \\ кандидат філологічних наук, \\ старший викладач кафедри прикладної лінгвістики \\ Начіональний університет кораблебудування імені адмірала Макарова \\ просп. Героїв Украӥни, 9, Миколаїв, Україна \\ orcid.org/0000-0003-3097-7878 \\ shcherbak.olena2410@gmail.com
}

\begin{abstract}
Ключові слова:
публіцистичний кінотекст, лінгвосеміотичний код, автор, герой, документ, кадр, титр, план.
\end{abstract}

Статтю присвячено проблемі виокремлення різновидів лінгвосеміотичних кодів і визначення специфіки їхнього функціонування в українських публіцистичних кінотекстах.

У роботі подано синтезовану інформацію про еволюцію поняття «код» iз презентацією найпопулярніших підходів до його трактувань, а також наведено аргументи на користь розгляду коду без ототожнення його 3 мовою.

Пояснено зміст поняття «кінотекст», на підставі цього запропоновано в його дослідженнях послуговуватися терміном «лінгвосеміотичний код», оскільки процес нейрофізіологічного сприйняття його вербальних і невербальних компонентів відбувається нерозривно, а конструювання його невербального ряду спирається на вербальний складник. Отже, лінгвосеміотичний код - це одноцільність знаків лінгвістичної та / або нелінгвістичної генези, план змісту та план форми яких водночас скеровано на реалізацію певної функції повідомлення, репрезентованого кодом.

Здійснено огляд розроблених ученими класифікацій кодів, зокрема й актуальних для кінотекстів, однак для обстеження публіцистичних кінотекстів рекомендовано виокремлювати три типи лінгвосеміотичних кодів $з$ огляду на їхню здатність реалізувати інформативність і впливовість відповідних повідомлень. До них уналежнено коди «Автор», «Герой», «Документ», що мають як вербальні, так і невербальні об'єктиватори.

Встановлено, що лінгвосеміотичний код «Автор» аудіально вербалізується за допомогою дейктичних слів (особові, присвійні та вказівні займенники), складних речень із підрядними умови, періодів, фразеологізмів, інколи гіпербол і цитат, а також візуально-графічно презентується у прикінцевих титрах у формі антропонімів. Своєю чергою, візуалізація цього коду забезпечується установочними кадрами та відзначається асоціативним зв’язком із його вербалікою. Лінгвосеміотичний код «Герой» виражається двома субкодами - «Експерт» і «Свідок», де для першого характерним $€$ вживання термінів, суспільно-політичної лексики, сленгізмів, а для другого - розмовних слів, вигуків і взагалі суржику, попри те, що обидва субкоди мають тотожну візуальну презентацію. Для реалізації їхніх функцій зазвичай використовуються середні перші плани зйомок осіб, дещо рідше - загальні та середні другі плани. Лінгвосеміотичний код «Документ» має збіги 3 кодом «Автор» у мовному оформленні, проте відрізняється своєю візуальною об’єктивацією, що здійснюється 3 використанням ефекту ретрокадрів та інтертитрів. 


\title{
LINGUOSEMIOTIC CODES AND SPECIFICS OF THE FUNCTIONING OF THEIR VARIETIES IN JOURNALIST CINEMA TEXTS
}

\author{
Shcherbak O. V. \\ Candidate of Philological Sciences, \\ Senior Lecturer at the Department of Applied Linguistics \\ Admiral Makarov National University of Shipbuilding \\ Heroes of Ukraine ave., 9, Mykolaiv, Ukraine \\ orcid.org/0000-0003-3097-7878 \\ shcherbak.olena2410@gmail.com
}

Key words: journalistic cinema text, linguosemiotic code, author, hero, document, frame, title, plan.
The article is devoted to the problem of isolating the varieties of linguosemiotic code, taking into account the specifics of their functioning in Ukrainian journalistic cinema texts.

The author presents the evolution of the concept of "code" with the most popular approaches to its interpretations, and also provides arguments in favor of the inexpediency to identify code and language.

The meaning of the term "cinema text" is explained too as a cooperation of linguistic and extralinguistic components. The use of the term "linguosemiotic code" in these studies is proposed, considering the fact that the process of neurophysiological perception of verbal and non-verbal components of this discourse is indissoluble and the formation of its non-verbal part is based on the verbal component. Therefore, the linguosemiotic code is a monolithic of verbal and / or non-verbal signs, in which the semantic scope and the formal image are aimed at ensuring the implementation of different functions of the message represented by the code.

The author considers classifications of codes. However, for the examination of journalistic cinema texts, it is recommended to distinguish three types of linguosemiotic codes, given their ability to implement the informativeness and impact of relevant messages. These include the codes "Author", "Hero", "Document", which have both verbal and non-verbal objectifiers.

It is established that the linguosemiotic code "Author" is audibly verbalized with the help of deictic words, complex sentences with subordinate clauses, periods, phraseologies, sometimes hyperbole and quotations. It is visually and graphically presented in final captions in the form of names too. The visualization of this code is provided by the installation frames and is marked by an associative connection with its verbal content. The linguosemiotic code "Hero" has two subcodes - "Expert" and "Witness", but the first is characterized by the use of terms, socio-political vocabulary, slang, and the second - colloquial words, exclamations and surzhik in general. To implement their functions, the average first plans of people and the general and average second plans are usually used. The linguosemiotic code "Document" coincides with the code "Author" in the language design, but differs in its visual objectification, which is carried out using the effect of retro frames and intertitles.
Постановка проблеми. За твердженням Н. Андрейчук, «лінгвосеміотичне бачення комунікативного процесу грунтується на його тлумаченні як процесу кодування та декодування структур смислу» [1, с. 10], у зв'язку із чим для здійснення відповідних дослідницьких операцій логічно звертатися до поняття «код». Воно вже стало ключовим для низки лінгвосеміотичних інспектувань комунікативних процесів у межах таких інституційних дискурсів, як художній (К. Свграшкіна, В. Мартинов, Н. Олизько), політичний (Р. Садуов), рекламний (Т. Безугла, Л. Кочетова, Т. Семенюк), театральний (А. Габдулліна), фармацевтичний (Г. Бурова) та інтернет-дискурс (В. Варзапова). Наявність кодів у кінодискурсі та й кінотекстах як його зразках також не заперечується товариством 
науковців (див. праці С. Зайченко, О. Колодіної, А. Корячкіної), однак моніторинг банку дисертаційних розвідок засвідчує, що вони здебільшого являють собою результат абдукції концепцій Р. Барта, Ю. Лотмана й У. Еко, лише поверхнево торкаючись питання лінгвістичної експлікації, хоч ще із середини XX ст. французький теоретик кіно К. Мец пропагує ідею про те, що «семіотика може й повинна сильно залежати від лінгвістики, проте іiі не варто ототожнювати 3 лінгвістикою» [10, с. 40]. Наведене якраз і переконує в актуальності пропонованої праці, що зумовлюється необхідністю деталізованої презентації кодової тектоніки кінотекстів 3 огляду на відсутність у лінгвістичній науці відповідних фундаментальних праць, посилюючись також спробою проведення дослідження на грунті українськомовних публіцистичних (документальні) кінотекстів, які до поглибленої лінгвосеміотичної обсервації 3 боку зарубіжних і вітчизняних учених ще не залучалися.

Мета і завдання статті. Мета статті - виокремлення різновидів лінгвосеміотичних кодів, актуальних для публіцистичних кінотекстів, i пояснення специфіки їхнього функціонування. Досягнення окресленої мети стане можливим шляхом консеквентного виконання таких завдань: 1) висвітлити зміст поняття «лінгвосеміотичний код»; 2) здійснити огляд наявних класифікацій та встановити різновиди лінгвосеміотичних кодів, актуальних для публіцистичних кінотекстів; 3) пояснити специфіку їхнього функціонування у фактажі роботи.

Предмет і об'єкт дослідження. Об'єктом дослідження обрано лінгвосеміотичні коди, наявні у структурі публіцистичних кінотекстів, а предметом - їхні типологічні різновиди та динаміку функціонування.

Джерельною базою роботи послужив текст (у широкому розумінні) публіцистичного кінофільму «Україна: еволюція гідності» (ТРК «Україна», 2019 р.) загальною тривалістю 1 година 22 хвилини, 3 якого до подальшого лінгвосеміотичного інспектування взято понад 300 речень та 350 кадрів, що і стали фактичним матеріалом дослідження.

Цільовий праксис дослідження, а також складність його об'єкта змотивували використання як загальнонаукових, так і спеціальних методів лінгвістики. Серед методів першої групи актуальними в роботі є описовий і метод спостереження, а також методи аналізу, синтезу й узагальнення, що загалом посприяли формуванню теоретичного фундаменту наукової статті, систематизації зібраного фактичного матеріалу та його кваліфікації. Завдяки методам класифікації та моделювання виокремлено лінгвосеміотичні коди у структурі публіцистичного кінотексту, проілюстровано їх. Застосування методу кількісного аналізу посприяло визначенню актуальних лінгвістичних та нелінгвістичних репрезентантів у межах кожного коду. Основним метод другої групи став функційний метод із його методикою контекстуально-інтерпретаційного аналізу, що використано з метою пояснення специфіки функціонування й об'єктивації кодів у досліджуваних матеріалах.

Виклад основного матеріалу дослідження. Термін «код» є базовим абсолютно для всіх галузей семіотики, однак витлумачується по-різному $[11$, c. 311$]$, зокрема й у парадигмі лінгвосеміотики, де вченими активно обстоюються дві діаметрально протилежні позиції: з одного боку, код $\epsilon$ синонімом понять «мова» та «мовна система» $[13$, с. 30], а $з$ іншого - код містить «не лише вербальні (мова), а й невербальні семіотичні системи (одяг, музика, жести)» [9, с. 53]. Ми, своєю чергою, схиляємося до доцільності широкого розуміння коду, спираючись також і на аргументи О. Кравченка, який запевняє, що «посилання на те, що мови подібні до певного стійкого коду, лежить в основі мовного міфу - доктрини, що утверджує, що мови складаються 3 наборів певних форм, використовуваних для «пересилання» повідомлень від відправника до одержувача, а саме це «пересилання» і становить сутність мовної комунікації» $[4$, с. 55-56], тобто «світ такий, яким його малює нам мова» [4, с. 56], апелюючи до того, що у протилежному випадку, «якщо мова - це код, прагматиці тут робити нічого» [4, с. 56]. Ця теза бачиться нам цілком аксіоматичною, оскільки сучасні фахівці, серед яких і фундаторка Одеської школи сугестивної лінгвістики Т. Ковалевська та iii учні, розуміють мову як «найважливішу категорію не лише осягнення світу (семантика), а і практичного впливу на інших людей (власне прагматика)» [3, с. 325].

Попри те, що кінотекст $є$ «ланцюжком ядрових кадрів» $[6$, с. 15], тобто первинною виступає його невербальна організація, усе ж він, як помічають Р. Стем, Р. Бургойн та С. Фліттерман-Льюїс, «не був застрахований від магнітного потягу лінгвістичної моделі» [13, с. 61], додаючи, що вже у 20-х рp. XX ст. теоретики кінематографа (Л. Делюк, Р. Канудо, В. Ліндсей) акцентували на мовоподібному характері кіно [13, с. 61]. Тому постулатом сьогодення вважається, що «чимало лінгвістичних особливостей кінотекстів, насамперед високий ступінь його імпліцитності, здебільшого зумовлено супроводом експліцитного (чи експлікуючого) відеоряду» [5, с. 126]. 3 огляду на це, а також зважаючи на результати досліджень канадських психологів А. Пайвіо та М. Садоскі, які демонструють, що, «безсумнівно, у сприйнятті й обробці вербальної інформації умовно домінує 
ліва півкуля головного мозку, а права півкуля бере участь у декодуванні візуальної або невербальної інформації, однак насправді ці дві ділянки кори головного мозку настільки тісно пов'язані одна 3 одною, що інформація, яка почала оброблятись однією півкулею, активізує чи дублює інформацію в іншій півкулі» [12, с. 81], для подальшого обстеження кінотекстів пропонуємо оперувати поняттям «лінгвосеміотичний код» (далі - ЛСК), розуміючи під ним одноцільність знаків лінгвістичної та / або нелінгвістичної генези, план змісту та план форми яких скеровано на реалізацію певної функції повідомлення, репрезентованого кодом.

У репозиторіях наукових праць налічується значна кількість класифікацій семіотичних кодів, розроблених на підставі застосування різних підходів. Помічено, що, наприклад, за ступенем поширення конвенції коди можуть бути загальні (широкі) й авторські (обмежені); за «характером домовленості» - одно- та двосторонні; за природою носія та сферою використання - вербальні, тілесні, поведінкові, масмедійні, регуляторні, естетичні, жанрові, стилістичні; за структурою - прості та складні [2, с. 50-53]. Нерідко вчені вдаються й до інших критеріїв для їхньої типологізації, виокремлюють за денотативністю / конотативністю, відповідно, денотативні та конотативні коди; за абстрактністю / конкретністю - абстрактні та конкретні; за характером структурних перетворень - трансляційні, поєднані, комбіновані; за лініями універсалій і патернів, універсалій i форм, універсалій і умовних знаків - коди універсалій, прототипів, форм, патернів, цілісностей [7] тощо. Для пояснення ж семіотичної організації кінотекстів найактивніше експлуатується класифікація У. Еко, який ідентифікував такі коди, як коди сприйняття, впізнання, передачі, а також тональні, іконічні, іконографічні, смакові, риторичні, стилістичні та підсвідомі (детальніше див. у [8]). За нашими спостереженнями й з опертям на той факт, що публіцистичні фільми виконують дві основні функції - інформаційну та впливову [6, с. 41], у структурі відповідних кінотекстів варто виокремлювати три типи ЛСК, уважаючи їх апріорно інформаційно-впливовими й такими, що репрезентуються на двох рівнях - лінгвістичному та нелінгвістичному:

1. ЛСК «Автор», що пов'язаний із позиціонуванням особистості масового або, рідко, індивідуального адресанта кінокомунікації, його поглядів, думок у прямий (присутність у кадрі) чи опосередкований (закадровий голос, диктор) спосіб.

Репрезентантами зазначеного ЛСК на лінгвістичному рівні, що апелюють до аудіального модусу сприйняття, щонайперше виступають дейктичні слова, серед яких особові та присвійні займенники (Кожного разу ми чекаємо, щзо вона здійснить наші мрії. Нас випробовують війною, нуждою, брехнею, але така ціна розвитку, ім'я якому - еволюиія), вказівні займенники (Це Майдан); слова-асоціати (Революція - це вибуx); а також складні речення 3 підрядними умови (Та його енергія згасне марно, якщи далі не буде руху), періоди (Крок за кроком, кілометр за кілометром - трансформачія буття, трансформація свідомості); метафори (Подалі від глухих кутів із сочіалістичною назвою «Русский мир»), фразеологізми (Раніше всі податки йшли до Києва і не поверталися назад, але з початком реформи левова частка грошей лишається на місиях), інколи й гіперболи (Довелось подолати тисячі кілометрів, щоб з'ясувати ие). Досить рідко автор озвучує цитати: «Без цісї допомоги, хто знає, як вижила б», - зізнається Ольга. Окрім цього, лінгвістичність ЛСК «Автор» інколи виражається й візуально. Це засвідчують насамперед антропоніми, наявні у прикінцевих титрах, у яких указуються імена журналістів, редакторів, сценаристів тощо, наприклад: диктор - Максим Сінчуков.

Нелінгвістична презентація ЛСК «Автор» апелює суто до візуального модусу сприйняття й об'єктивується в установочних кадрах, що мають на меті дати глядачам візуальну підказку щодо часу, місця та загальної ситуації, про які йтиметься у фільмі. У нашому фактичному матеріалі такими установочними кадрами $є$ натурні зйомки залізниці, якою 3 високою швидкістю пересувається потяг. Відзначимо, що прямої кореляції картинки 3 лінгвістичним контентом цього ЛСК немає, однак такий зв'язок можна схарактеризувати як асоціативний, оскільки авторські висловлювання грунтуються на поняттях «рух», «дорога», «швидкість» і суміжних із ними (Уже не треба рятувати ї̈ з пекла 2014 р., але треба повести ї̈ рівною дорогою до мети. П'ять років тому ми рушили в напрямку цивілізованого світу. Важливо не схибити на цьому шляху!).

2. ЛСК «Герой», що пов'язаний із лінгвістично-нелінгвістичним позиціонуванням осіб, запрошених до зйомок для надання певної інформації інтерв'юеру з питань, що порушуються у фільмі. Особливістю цього ЛСК є те, що він об'єктивується у двох так званих субкодах - субкоді «Експерт» та субкоді «Свідок», де перший стосується фахівців, які здебільшого дають аналітику подіям, що відбулися, а також роблять певні прогнози; другий же стосується спостерігачів та безпосередніх учасників подій, які повідомляють про факти власної біографії чи біографій знайомих їм людей.

Субкод «Експерт» із лінгвістичного погляду відзначається функціонуванням у ньому термінів 
(репліка А. Яценюка: Їм дають фіктивні цілі, де виділене словосполучення $\epsilon$ психологічним терміном); суспільно-політичної лексики (репліка В. Гройсмана: Я пам'ятаю, як ми запровадили з першого січня фінансову децентралізацію. Якщо ви візьмете виступи депутатів, фракцій на той час, ви побачите, як вони мене нещадно критикували), а також сленгізми (репліка Л. Гриневич: Власне безвіз розкрив нові можливості для стажування, студентського обміну, викладащького обміну).

Субкод «Свідок», на відміну від попереднього субкоду, хоч і має маркери літературної мови, проте в ньому досить часто функціонують розмовні слова та суржик (репліки О. Шереметьєвої: Усі розрахунки, які в нас єсть на розвиток інфраструктури, на реалізацію проєктів. Розвиток інфраструктури - ие школи, клуби, спортивні площадки, дороги, вуличне освітлення, - ми ділимо на кількість людей. Реформа ия робилася для людей. Значить, на кожну людину ми повинні розпрідилити кошти), а також і слова-вигуки (Ось у иій половині була < ..> ну як < ..> медпункт був, а у тій половині була бібліотека <..> раніше). Окрім цього, є приклади надання відповідей на питання інтерв'юера російською мовою, зокрема це стосується зйомок та інтерв'ювання людей у Киргизстані (див. фільм із 66 хвилини).

Нелінгвістичні інструменти презентації двох субкодів ЛСК «Герой» виявляються абсолютно тотожними як у типологічному, так і у функційному аспектах. Ними виявляються середні перші плани зйомок осіб, які коментують проблему чи подію, а також загальні та середні другі плани, що фіксуються в кадрах, які $є$ унаочненням чи підтвердженням того, про що говорить герой. Наприклад, на 60-й хвилині фільму з'являються кадри амбулаторії с. Рокитного Полтавської області, іiї інтер'єрів, обладнання, персоналу, який працює. Паралельно із цим коментар комплементарного характеру дає свідок, яким виступає О. Шереметьєва: Сьогодні ви були там $і$ бачили амбулаторію, де куплена машина, де є світло, де $\epsilon$ стоматолог. Звідси випливає, що функційно нелінгвістичні об'єктиватори в межах цього коду тяжіють до візуального каналу сприйняття, проте активують і аудіальний.

3. ЛСК «Документ», що пов'язаний із презентацією реальності, що становить проблему фільму й досліджується в ньому. Зазвичай основними репрезентантами цього коду виступають архівні тексти (з відео- та / або аудіосупроводом), що якраз і засвідчують реальність подій і фактів, згадуваних у фільмі.

Помічено, що лінгвістичний контент цього коду практично цілком збігається 3 відповідним рівнем ЛСК «Автор» (див. вище), оскільки в ньому також презентується особистість автора відзнятих не для публіцистичного кіно й за певний час до його створення репортажів та інших відеоматеріалів, щоправда, меншою мірою. Головна відмінність ЛСК «Документ» від інших кодів публіцистичного кінотексту виявляється у специфічній візуальній репрезентації, що полягає в застосуванні ефекту ретрокадрів, що дозволяють глядачам без додаткових когнітивних дій відрізнити сучасне та минуле (див., напр., фільм на 18-й хвилині, коли на екрані показано кадри, відзняті під час мітингу у вірменському місті Гюмрі у 2015 р., тобто за чотири роки до прем'єрного показу досліджуваного фільму). Також із цією метою в кінотексті використовуються й інтертитри, які додатково інформують глядача про те, що відеоряд є належним до архівних матеріалів. Як приклад див. напис у лівому верхньому кутку відповідних кінокадрів: Архів. Гюмрі, 2015 p.

Висновки і перспективи подальших розробок. Публіцистичний кінотекст $є$ системою взаємопов'язаних і невіддільних один від одного знаків лінгвістичної та нелінгвістичної генези. У зв'язку із цим під час проведення лінгвосеміотичних обстежень відповідних матеріалів доцільно послуговуватися терміном «лінгвосеміотичний код», що, своєю чергою, забезпечує кінотекстам інформативність і впливовість, а також репрезентується у трьох видах - «Автор», «Герой», «Документ». Перший і останній ЛСК мають однаковий лінгвістичний контент, проте відрізняються лише за суто візуальною формою, оскільки для ЛСК «Документ» характерним $є$ навмисне використання ефектів. Свою чергою, ЛСК «Герой» також має власну відмінність від решти ЛСК: він об'єктивується у двох субкодах («Експерт» і «Свідок»), відзначається наявністю маркерів як літературної, так і нелітературної мови, виявляе константність у використанні планів для формування відеоряду.

Перспективи подальших розробок убачаємо у здійсненні лінгвосеміотичного аналізу публіцистичних кінотекстів із деталізацією впливової зумовленості його структурних блоків, залучивши для цього інструменти нейролінгвістичного програмування, скерованого якраз «на дослідження когнітивних структур людини, пов'язаних зі специфічними процесами діакритизації метатексту дійсності та відповідною експлікацією вербалізованих і аналогових моделей у полікомунікативних площинах» $[3$, с. 325$]$.

\section{ЛІТЕРАТУРА}

1. Андрейчук Н.І. Потенціал лінгвосеміотичної інтерпретації для розвитку перекладознавчих студій. Записки з романо-германської філолоziï. 2015. Вип. 1. С. 8-14. 
2. Бразговская Е.Е. Языки и коды. Введение в семиотику культуры : учебное пособие. Пермь : Перм. гос. ин-т искусства и культуры 2008. $201 \mathrm{c}$.

3. Ковалевська Т.Ю. Актуальні напрями дослідження вербальної сугестії. Одеська лінгвістична школа: інтеграчія підходів : колективна монографія / за заг. ред. Т.Ю. Ковалевської Одеса : видавець Букаєв Вадим Вікторович, 2014. C. 323-331.

4. Кравченко А.В. Биологическая реальность языка. Вопросы когнитивной лингвистики. 2013. № 1 (034). С. 55-63.

5. Кустова О.Ю. Концептуальные модели исследования киноперевода. Известия Российского государственного педагогического университета имени А.И. Гериена. 2019. № 192. C. $123-130$.

6. Слышкин Г.Г., Ефремова М.А. Кинотекст (опыт лингвокультурологического анализа). Москва : Водолей Publishers, 2004. 153 c.

7. Сомов Г.Ю. Проблема кодов в семиотике и пути междисциплинарного теоретического синтеза. URL: http://gsomov.com/problemakodov-v-semiotike-i-puti-mezhdisciplinarnogoteoreticheskogo-sinteza/.

8. Эко У. Отсутствующая структура. Введение в семиологию / пер. с итал. В.Г. Резник, А.Г. Погоняйло. Санкт-Петербург : Simposium, 2006. 544 c.

9. Danesi M. Encyclopedic Dictionary of Semiotics, Media, and Communications. Toronto : University of Toronto Press, 2000. 199 p.

10. Film Language. A Semiotics of the Cinema / Christian Metz ; Translated by M. Taylor. Chicago : The University of Chicago Press, 1991. $268 \mathrm{p}$.

11. Kourdis E. The Notion of Code in Semiotics and Semiotically Informed Translation Studies. A Preliminary Study. Readings in Numanities. 2018. P. 311-325.

12. Paivio A., Sadoski M. Imagery and Text: A Dual Coding Theory of Reading and Writing. London and New York : Routledge, 2013. 165 p.

13. Stam R., Burgoyne R., Flitterman-Lewis S. New Vocabularies in Film Semiotics. Structuralism, post-structuralism and beyond. London and New York : Taylor and Francis Inc., 2005. 246 p. DOI: $10.4324 / 9780203977194$.

\section{REFERENCES}

1. Andreychuk, N.I. (2015) The potential of linguistic and semiotic interpretation for the translation studies' development [Potentsial linhvosemiotychnoyi interpretatsiyi dlya rozvytku perekladoznavchykh studiy]. Zapysky z romano-hermanskoyi filolohiyi, vol. 1, pp. 8-14.

2. Brazgovskaya, E.E. (2008) Languages and codes. Introduction to the semiotics of culture [Yazyki $i$ kody. Vvedeniye v semiotiku kultury]. Perm State Inst. of Arts and Culture, Perm, $201 \mathrm{p}$.

3. Kovalevska, T.Yu. (2014) Actual directions of research of verbal suggestion [Aktual'ni napryamy doslidzhennya verbal'noyi suhestiyi]. Odes'ka linhvistychna shkola: intehratsiya pidkhodiv. Publisher Bukaev Vadym Viktorovych, Odesa, pp. 323-331.

4. Kravchenko, A.V. (2013). Biological reality of language [Biologicheskaya real'nost' yazyka]. Voprosy kognitivnoy lingvistiki, vol. 1 (034), pp. 55-63.

5. Kustova, O.Yu. (2019) Conceptual models of film translation research [Kontseptual'nyye modeli issledovaniya kinoperevoda]. Izvestiya $R G P U$ im. A.I. Gertsena, vol. 192, pp. 123-130.

6. Slyshkin, G.G., Efremova, M.A. (2004) Kinotext (experience of linguoculturological analysis) [Kinotekst (opyt lingvokulturologicheskogo analiza)]. Aquarius Publishers, Moscow, 153 p.

7. Somov, G.Yu. (2017) The problem of codes in semiotics and the ways of interdisciplinary theoretical synthesis [Problema kodov v semiotike $i$ puti mezhdistsiplinarnogo teoreticheskogo sinteza]. URL: http://gsomov.com/problemakodov-v-semiotike-i-puti-mezhdisciplinarnogoteoreticheskogo-sinteza/ (October, 7, 2021).

8. Eco, U. (2006) Absent structure. Introduction to semiology [Otsutstvuyushchaya struktura. Vvedeniye $v$ semiologiyu]. Simposium, St. Petersburg, $544 \mathrm{p}$.

9. Danesi, M. (2000). Encyclopedic Dictionary of Semiotics, Media, and Communications. University of Toronto Press, Toronto, $199 \mathrm{p}$.

10. Metz, Ch. (1991) Film Language. A Semiotics of the Cinema / Translated by M. Taylor. The University of Chicago Press, Chicago, 1991. $268 \mathrm{p}$.

11. Kourdis, E. (2018) The Notion of Code in Semiotics and Semiotically Informed Translation Studies. A Preliminary Study. Readings in Numanities, pp. 311-325.

12. Paivio, A., Sadoski, M. (2013) Imagery and Text: A Dual Coding Theory of Reading and Writing. Routledge, London and New York, $165 \mathrm{p}$.

13. Stam, R., Burgoyne, R., Flitterman-Lewis, S. (2005) New vocabularies in film semiotics: Structuralism, post-structuralism and beyond. Taylor and Francis Inc. 246 p. DOI: $10.4324 / 9780203977194$. 